\title{
Literature? In Substitution for Legal Philosophy? (Variations to and Uses of "Law and Literature")
}

\begin{abstract}
Anglo-American and French, as well as German, Spanish and Hungarian variations to "Law and Literature" are surveyed for that as to the nature of the discipline some conclusions can be formulated. Accordingly, "Law and Literature" recalls that which is infinite in fallibility and which is not transparent in its simplicity, that is, the situation confronted that we may not avoid deciding about despite the fact that we may not get to a final understanding. What is said thereby is that "Law and Literature" is just a life-substitute. Like an artificial ersatz, it helps one to see out from what he/she cannot surpass. What it is all about is perhaps not simply bridging the gap between the law's proposition and the case of law, with unavoidable tensions confronting the general and the individual, as well as the abstract and the concrete. Instead, it is more about live meditation, professional methodicalness stepped back in order to gain further perspectives and renewed reflection from a distance, so that the underlying reason for the legal (and especially judicial) profession can be recurrently rethought. In a fictional form, literature is the symbol and synonym of reflected life, a field where genuine human fates can be represented. Thereby, at the same time it is a substitute for theology, rooted in earthly existence as a supply to foster feeling kinds of, or substitutes to, transcendence.
\end{abstract}

Keywords: enigma of law, Shakespeare, Madách's The Tragedy of Man, Kleist's Michael Kohlhaas, Sophocles' Antigoné, Dostoyevsky

\section{The Enigma of Law and its Study}

"Law and Literature"? It helps human quality to enrich us. It helps channel back again into the law's domain that which is endless and incomprehensible throughout, and which escapes from all final explanation. It reconstructs the milieu in which we can float at most but which we will never have acquired. It helps us recognise in our existence the image of God we can hardly perceive with eyes dedicated to earthy matters. It helps us cogitate about the mystery of our existence in the Universe, the existential unthinkability of our presence thrown into being. It helps the human quality restored in us, whereto we still always escape back when our artificial being in this very world makes us dry, shrivelled, empty or weightless.

As is commonly known, our science is great albeit hyperbolic. We provided ourselves with scientific methodology to proceed step by step with the help of the logic of a world we made from ideas and conceptualised, and we erect intellectual buildings by executing relentless demands drawn from it. By the same token, in the meantime, however, we inevitably also deconstruct our world. And, thereby, we transformed that which has been so deep as to be impossible to break through and untransparently phenomenal, into simplicity reduced until it could be seen from one single aspect that we have sliced out of it. Moreover, we also prescribed what to see in it, and we also slowly began to see it-and nothing except it-indeed.

* Scientific Adviser, Institute for Legal Studies of the Hungarian Academy of Sciences, H-1014 Budapest, Országház u. 30; Professor, Director of the Institute for Legal Philosophy of the Catholic University of Hungary, H-1088, Budapest, Szentkirályi u. 28-30.

E-mail: varga@jog.mta.hu; homepage: http://drcsabavarga.wordpress.com 
Hoping for a securer state, we built a fortress we believed to be firm as a rock around ourselves from mere consequences. We bedded ourselves methodically into mortar as far as we could; and on the fundament of our estate under our soles we scan the firmament to foresee whether or not we may once put even stars under the settling yoke of our intellect. When walking proudly and bravely, we think to navigate our existence on the field we have created without recognising that we have augmented it by a ballast in the meantime. For if sky and earth quake, we have to realise that we find ourselves in the old uncertainty. As lotus or corals live in water and others do live on them, we cuddle up together. And although flood floats and waves play with us with tide raising and sinking, in our misappointed sense-feeling ourselves at home in such a floating-we constitute, hand in hand, a standing mainland for ourselves.

Thus, our scholarship is great even if hyperbolic. It forecalculates how and in what way we should go on, and we may know whether we have gone on actually, because we may come on steadily indeed. For in that it has a message at all, it tells the truth. For we may actually delve into it deeper with the help of methodicality-with regard to all matters we may be at all immersed in. Our civilisation is pushed by our scholarship increasingly further; thus, we dig even deeper and deeper until, slowly, our sight will be lost. Sometimes we already forget where we have begun to dig at all. By now we mostly see-exclusively, even if ever from nearer-that which we may sense on the edge of our spade. And the more our eye becomes accustomed to it, the less sight remains to see anything else. Whilst we approach, we also drift apart inevitably.

Indeed, science is to be found wherein there is sacrifice, too. This is where it is important-unavoidably-to develop partialities in ourselves. This is where we make order by fabricating concepts for ourselves, and also by establishing necessary links as laws amongst them. And independent of how much uncertain it is-both from where it starts and where it concludes-we call such links established as knowledge by right, because we get more by it than otherwise. In this manner, we have already built an artificial world around ourselves.

Under such conditions, it is worthwhile to know what we are actually doing, so that after having made a sacrifice for it, we may also rebuild the fullness of our human beings. For we may get used to our new world to a great extent. And we should realise after all that our science has never been and will never be anything complete or completed. Certainly, the outcome is not reality itself but alter ego humanly constructed and construed, which we have made primitive by virtualising as slices of what God created or what happened to us, i.e. as proofs and stems remaining in our sense. All this is as if we magically identified ourselves with something else, and for this, we build for our own use, from twigs and leaves, entities-animals or humans-living as a cosmos in themselves. Well, the actuality produced by our scholarship as a world of concepts is by no means more viable in itself than the noble action of our magical act. And still: if it is feasible to do that and that can be learnt and practiced, then we may precipitate effects through such substitutes, too.

In sum, there is science. It also has to be as it proved to be useful for humanity, in the humans' earthly struggle.

\section{2. "Law and Literature"}

Law is scholarship on human ordering. It addresses the issue as to whom anything may be attributed and ascribed, and in what, and how, proper balance should be manifested, a balance that we would like to measure, with scales set up in our earthly existence. In the final account, our law is the constant refinement of the autocracy of human will through various deflectors. 
Whilst we spade even deeper in our scholarship on human ordering, we become in fact already increasingly involved in ourselves by our deflectors, driven by and getting entangled with other deflectors. After a while, sometimes we cannot any longer know for sure what is actually driven by what. And if, instead of an appeal to, or interest in, our choice, namely, of our human fallibility, we try to read the scale from the miracle of Creation, then the innocence of admiration, of the mysticism of reunion with the divine essence, of the maiden and still devoted astonishment will also sooner or later be replaced by a scale reading as transformed into its own and distinct profession, which, through its artificial ways, will achieve its methodicality born from that professionalisation so that, eventually, it cannot see in its selfmirror anything else than its own self, virtualised by its own means.

Law, then literature? Literature, then law? Even the expression makes them transcendent as there is neither law, nor literature inside. The profession of jurisprudence, always sinking into its own devices while becoming emotionless as to the grandiose donation capable of being astonished at the real world, looks in and through them-as the primitively taintless expression of anything human (compared to legal artificiality)-for the heady clarity of fullness and for the regenerating force of its conception, which withstands explanations to the very being.

Returning back to the original indication: "Law and literature"? Well, "law" here is what it is not any longer and, in turn, "literature"-that is all. Like The Jolly Joker (as an extra trump card), "literature" in such a connection is all that is still capable in our world of giving an account of the fullness of being lost repeatedly, so as to realise newly its inexhaustibility, and to persuade us as to the original fallibility of whatever explanation and final setting, with the limited devices at our disposal. Therefore, it can stand for anything else and it will depend on custom, fashion or just any occasional mainstream idea, whether we hold onto whatever word, human expression or catharsis that is recurrently sensed by humans in its naming. Since it could as well be fable or myth, a primitive popular event shooting out from atavistically ancient directness, just as well as the playing of a string quartet, thunderstorm or volcano breakout, or again, the playing of moths or animal rut. We call it 'literature' as we do also mostly rely on text, with an understanding of texts and contexts in it. We refer to it as if understanding a text differed from understanding a world. That is, we act as if law were simple text-reproducing concretisation, instead of the (unmatched but always accessible) wisdom of the realisation that we weigh much and many times whilst we equalise balance only rarely-at a time when we can hardly do anything else. For, we hardly abide by anything else in law than tradition, within the frameworks of which we wish exactly-and just through the law and its responsively responsible practice-to relax.

Hamlet? Michael Kohlhaas? Raskolnikov? Heroes of Franz Kafka, Robert Musil, William Shakespeare, Heinrich von Kleist and Fyodor Dostoyevsky coming out from and then returning to fog? Instead of the self-reassuring conformism of the peacockery of hypocrisy, Friedrich Nietzsche shouted to the world the majestic royal nudity of Humanism still based on the Enlightenment. In lack of any resignation resulting from unprocessed conscience, Sören Kierkegaard concluded, in turn, a self-loss of being thrown into existence. Now, where are we ourselves? And what may we do mainly? For want of anything better, meditate while in front of our wise books, reading The Trial of the Genius by Barna Horváth ${ }^{1}$ in order to care, protect and defend ourselves, and even more so at a time when we have

${ }^{1}$ Horváth, B.: Der Rechtsstreit des Genius: I. Sokrates and II. Johanna, a) Der Tatbestand and b) Das Verfahren. Zeitschrift für öffentliches Recht, 22 (1942), 126-162, 295-342 and 395-460. 
already begun to choke from our own playing of false self-reassurance, still rounded off to mere geometry or rhetoric in our retained honesty. It seems to be purposeless to have constructed, like the Chess Turk by Wolfgang von Kempelen, ${ }^{2}$ a lawyer moved by pistonvalves of the rationale of some selected schemes. ${ }^{3}$ This is so because all that notwithstanding, a human is hidden in the machinery, behind the bewigged-cloaked external appearances. That is, what is hidden is not rationality disciplined in The Turk's torso but benevolence, mixed with fallibility, because there is a spell of drama in the air when the lawyer starts calculating or concluding a deal with an apparently cool head. The tempting remembrance of the Greek theatre ${ }^{4}$ is not by chance, therefore. For all those fighting are humans, although mere fate will decide after all. We rectify, and intervene to struggle with self-created rules, which could perhaps be cruder without us; we even try to hold down the hand of the fate, although no human effort is ever to succeed in full. We may have fought ourselves to get into the arena without, however, pushing out fate's hand. In turn, we are already so many and flail with so wide a range of weapons that sometimes we already trample each other; moreover, here and now we ourselves stumble upon our deflecting devices more and more.

What remains still? Nothing else but struggle and confidence. Can fight and trust be added to them? They are a strange combination at first glance, since the former was already practiced before the law, and the latter serves as a balm despite the law, too. And then, what might be the lesson to be drawn from all this? Maybe the first is the fact that no device can dispense of a manufacturer. Later on, it does not work instead of or without a user. Therefore, we have to resist the command of the self-laudating idol in front of us that, instead of the Good Lord, would make us adore this humanly created civilisation up to the point when, grovelling in front of it, we would also give up our civility and responsibility.

"Law and Literature" recalls that which is infinite in fallibility and which is not transparent in its simplicity, that is, the situation confronted that we may not avoid deciding about despite the fact that we may not get to a final understanding. This is so because we may tear much from the wires, albeit we cannot solve their totality. What is said here and now-for want of anything better-as "Law and Literature" is, therefore, only a life-substitute. Like an artificial ersatz, it helps us to see out from our everyday complexities, exemplifying why our personal existence is difficult to grasp, a condition that we cannot surpass, even if we may improve it to make it more noble with love offered to everyone. All this is like a monastic psalm: they do and we do what we all have to do, as this is the only thing that may convey meaning on our daily efforts, on human labour, without being able to replace it. This is one of the chances which we may securely draw on.

2 Cf. <http://www.kempelen.hu/index_en.html>, <http://en.wikipedia.org/wiki/The_Turk $>$ and $<\mathrm{http}: / /$ www.museumofhoaxes.com/hoax/Hoaxipedia/Great_Chess_Automaton/>.

3 Cf. Varga, Cs.: Leibniz und die Frage der rechtlichen Systembildung. In: Mollnau, K. A. (hrsg.): Materialismus und Idealismus im Rechtsdenken: Geschichte und Gegenwart. Stuttgart, 1987. 114-127.

${ }^{4}$ What will survive in medieval mysterium and morality plays or school dramas unchangingly unifying theatric performance and justice publicly administered, with experiencing the transmission of community messages as a community function. Cf., e.g. Gillespie, J. C.: Theatrical Justice. Northern Ireland Legal Quarterly, 31 (1980), 67-72. as well as-equipped with sharpened problemcentredness-Garfinkel, H.: Conditions of Successful Degradation Ceremonies. American Journal of Sociology, 61 (1956), 420-424. For a summary, see Tindemans, K.: Recht en tragedie: De scène van de wet in de antieke polis. [Diss.] Leuven, 1995/1996. 


\section{Varieties of "Law and Literature"}

"Law and Literature"? We may brood over the helplessly expansive imperialism of the caducity of great nations, the undemanding servility of the self-emptying confidence of past conquerors, when their gloire has already dissipated.

Law and Literature differs from its antecedents. In the thoroughly based AngloAmerican classical studies of more than a century ago, the literary analogon (either in personal paths of life or in problematic) still served as the medium of professional leisurely adventure; ${ }^{5}$ and Shakespeare's oeuvre was used (in general ${ }^{6}$ or as concentrated on his individual pieces, figures, topoi, ${ }^{7}$ or as connected with his once lawyerly professional

${ }^{5}$ Its early treatments-with the exception to, e.g. Andrews, W. (ed.): The Lawyer: In History, Literature, and Humour. London, 1896-were hardly more than collections of interesting features of mere biographical data-, e.g. Hawes, G. R.: Literature and the Law. The Green Bag [An Entertaining Magazine for Lawyers], 11 (1899), 234-237 and Westley, G. H.: From Law to Literature. The Green Bag, 12 (1900), 446-449-or dythirambs of the literary value of old lawyerly documents-Holdsworth, W. S.: Literature in Law Books. Washington University Law Quarterly, 24 (1939), 153-172-or a series of free associations on the ungraspability of anything law-, e.g. Cardozo, B. N.: Law and Literature. [Yale Review (1925) reprint] Columbia Law Review, 39 (1939), 119-137-, and it is only at a later time that analyses with a philological care will crop up-, e.g. from two periods of time, Cahn, E. N.: Goethe's View of Law, with a Gloss out of Plato. Columbia Law Review, 49 (1949), 904-920 and Boland, D.: Images of Law in Classical Russian Literature. Irish Student Law Review, 8 (2000), 53-65-and mostly for a propedeutic purpose.

${ }^{6}$ Cf., e.g. Heard, F. F.: Shakespeare as a Lawyer. Boston, 1883; Davis, C. K.: The Law in Shakespeare. 2nd ed., St. Paul, 1884; White, E. J.: Commentaries on the Law in Shakespeare, with Explanations of the Legal Terms Used in the Plays, Poems and Sonnets, and a Consideration of the Criminal Types Presented, also a Full Discussion of the Bacon-Shakespeare Controversy. 2nd ed., St. Louis, 1913; Greenwood, G.: Shakespeare's Law. London, 1920; Barton, D. P.: Links between Shakespeare and the Law. London, 1929; Keeton, G. W.: Shakespeare and his Legal Problems. London, 1930; Keeton, G. W.: Shakespeare's Legal and Political Background. New York, 1968; Phillips, O. W.: Shakespeare and the Lawyers. London, 1972; MacKinnon, F. V.: The Timeless Shakespeare: The Natural Law in Shakespeare. Gloucester, 1985; Wells, R. H.: Shakespeare, Politics and the State. London and Basingstoke, 1986; Cook, N. L.: Shakespeare Comes to the Law School Classroom. Denver University Law Review, 68 (1988), 387-411; Kornstein, D. J.: Kill all the Lawyers? Shakespeare's Legal Appeal. Princeton, 1994; Ward, I.: A Kingdom for a Stage, Princes to Act: Shakespeare and the Art of Government. Nottingham, 1997 and Ward, I.: Shakespeare and the Legal Imagination. London, 1999; Sokol, B. J.-Sokol, M.: Shakespeare's Legal Language. London and New Brunswick, 2000.

7 Cf., e.g. Guernsey, R. S.: Ecclesiastical Law in Hamlet: The Burial of Ophelia. New York, 1885; Clarkson, P. S.-Warren, C. T.: The Law of Property in Shakespeare and the Elizabethan Drama. Baltimore, 1942; Gless, D. J.: Measure for Measure: The Law, and the Convent. Princeton, 1979; Clark, A. M.: Murder under Trust, or the Topical Macbeth and Other Jacobean Matters. Edinburgh, 1981; Gohn, J. B.: Richard II: Shakespeare's Legal Brief on the Royal Prerogative and the Succession to the Throne. Georgetown Law Journal, 70 (1982), 943-973; Hamilton, D. B.: The State of Law in Richard II. Shakespeare Quarterly, 34 (1983), 5-17; Klein, H.-Dávidházi, P. (eds): Shakespeare and Hungary: The Law and Shakespeare. Lewiston, 1996; Hawley, W. M.: Shakespearean Tragedy and the Common Law: The Art of Punishment. New York, 1998; Kahn, P. W.: Law and Love: The Trials of King Lear. New Haven, 2000; Sokol, B. J.-Sokol, M.: Shakespeare, Law, and Marriage. Cambridge and New York, 2003; McDonald, M. A.: Shakespeare's King Lear with The Tempest: The Discovery of Nature and the Recovery of Classical Natural Right. Lanham and Oxford, 2004. 
practice $^{8}$ ) as a theological, ethical or political warehouse of patterns to forge an understanding of the nature and infinity of law as one of the deepest human challenges; jurist authors in that period turned with interest to other literary manifestations, too, ${ }^{9}$ just as they constructed examples in the fine arts ${ }^{10}$ or architecture. ${ }^{11}$ By contrast, as Law and Literature expressedly becomes a movement in the United States of America, ${ }^{12}$ it is not a product of philosophical

8 Cf., e.g. Hicks, F. C.: Was Shakespeare a Lawyer? A Review of the Literature in Question. Case and Comment [Rochester, N.Y.], 22 (1916), 1002-1011; Law, E.: Shakespeare's »Tempest " as Originally Produced at Court. London, 1920; Knight, W. N.: Shakespeare's Hidden Life: Shakespeare at the Law (1585-1595). New York, 1973; Kornstein, D. J.: Kill all the Lawyers? Shakespeare's Legal Appeal. Lincoln and London, 2005.

9 E.g. Hester, D. A.: Law and Piety in the »Antigone«: A Reply to J. Dalfen, »Gesetz ist nicht Gesetz...«. Wiener Studien, 14 (1980), 5-11; Hornsby, J. A.: Chaucer and the Law. London and Norman, 1988; Cambridge, R.: Aequitas and Iustitia in Mediaeval German Psalters. In: Mediaeval German Studies Presented to Frederick Norman. London, 1965. 31-38; Kirchberger, L.: Franz Kafka's Use of Law in Fiction: A New Interpretation of In der Strafkolonie, Der Prozess, and Das Schloss. New York, 1986; Islawm, S.: Kipling's »Law«: A Study of his Philosophy of Life. London, 1975; Hildebrand, E. G.: Jane Austen and the Law. Persuasions [Journal of the Jane Austen Society of North America], 4 (1982), 34-41 and Treitel, G. H.: Jane Austen and the Law. Law Quarterly Review, 100 (1984), 549-586; Simon, E.: Palais de Justice and Poetic Justice in Albert Camus. The Stranger' Cardozo Studies in Law and Literature, 3 (1990), 111-125.

10 E.g. Wind, E.: Platonic Justice, Designed by Raphael. Journal of the Warburg and Courtauld Institutes, 1 (1937-1938), 69-70; Cummings, F.: Poussin, Haydon, and The Judgement of Solomon. The Burlington Magazine, 104 (1962), 146-152; Puttfarken, T.: Golden Age and Justice in SixteenthCentury Florentine Political Thought and Imagery: Observations on Three Pictures by Jacopo Zucchi. Journal of the Warburg and Courtauld Institutes, 43 (1980), 130-149; Riess, J. B.: Political Ideals in Medieval Italian Art: The Frescoes in the Palazzo dei Priori [Perugia (1297)]. Ann Arbor, 1981; Tiefenbrun, S. (ed.): Law and the Arts. Westport and London, 1998.

${ }^{11}$ Interestingly enough, English-American pragmatism produced a lot on this field like, e.g. Taylor, K. F.: In the Theater of Criminal Justice: The Palais de Justice in Second Empire Paris. Princeton, 1993; Graham, C.: Ordering Law: The Architectural and Social History of the English Law Court to 1914. Burlington, 2003; McNamara, M. J.: From Tavern to Courthouse: Architecture and Ritual in American Law (1658-1860). Baltimore and London, 2004.

12 Just to mention few inspiring representatives, cf., e.g. Fish, S.: Working on the Chain Gang: Interpretation in the Law and in Literary Criticism. [Critical Inquiry 9 (1982), 201 et seq. reprint] in his: Doing What Comes Naturally: Change, Rhetoric, and the Practice of Theory in Literary and Legal Studies. Oxford, 1989, 87-103; Levinson, S.: Law as Literature. Texas Law Review, 60 (1982), 373-403; White, J. B.: Reading Law and Reading Literature. Texas Law Review, 60 (1982), 415-445; Weisberg, R. H.: The Failure of the Word: The Protagonist as Lawyer in Modern Fiction. New Haven and London, 1984; White, J. B.: When Words Lose their Meaning: Constitutions and Reconstitutions of Language, Character, and Community. Chicago and London, 1984 and Heracles'Bow: Essays on the Rhetoric and Poetics of the Law. Madison, 1985; West, R.: Jurisprudence as Narrative: An Aesthetic Analysis of Modern Legal Thought. New York University Law Review, 60 (1985), 145-211; Posner, R.: Law and Literature: A Misunderstood Relation. Cambridge and London, 1988; Levinson, S. and Mailloux, S. (ed.): Interpreting Law and Literature: A Hermeneutic Reader. Evanston, 1988; Weisberg, R.: The Law-Literature Enterprise. Yale Journal of Law and the Humanities, 1 (1988), 1-67; West, R.: Communities, Texts, and Law: Reflections on the Law and Literature Movement. Yale Journal of Law and the Humanities, 1 (1988), 129-156; White, J. B.: What Can a Lawyer Learn from Literature? Harvard Law Review, 102 (1989), 2014-2047; Weisberg, R.: Poethics and Other Strategies of Law and Literature. New York, 1992; White, J. B.: Acts of Hope: Creating Authority in Literature, Law, and Politics. Chicago and London, 1994; Ward, I.: Law and Literature: Possibilities and Perspectives. Cambridge, 1995. 
self-reflection pressed any longer without interests but is a device for avoiding scientific methodicalness in tribal discordance resulting from brutalised inside fights, when demands are launched and historical entitlements are declared. I am the one who once took part in the parade of the American world when saloon-Trotskyists, hidden in the mantle of the mainstream Critical Legal Studies, with unbarbered heads and in unwashed engine uniforms, flung in the face of wondering European legal sociologists: "Then damn the theory!"-although those latter asked only for the basis of this new-world toy, which played many times with us as a subversion, at an international scientific conference summoned at Onati in the Basque Country-and saw his friends, theorists of Harvard with international reputations who could whisper about the line that cannot be easily found between respectability and political correctness. So too I was the one who took part in the Anglo-American Critical Legal Studies meeting in the crumbling New College building in Oxford, convened for a fashionable meditation limited to criticism, when on the cocktail-grass of the break the distinguished guest, me, invited from Hungary, having noticed the always closed gate of the ancient chapel opening for a few minutes for ritual reasons, called out ardently, and the domestic participants, recruited from suburbs, as new staff without the antique titles of their Bodleian Library having ever been used, reproved immediately the intruder: "Up? To church? Why? We never go there!". Well, accordingly my ruminations formed from such experiences and my Australian and American impressions of three decades ago, the revolutionism of the generation of 1968 culminated first in so-called Critical Legal Studies. Then, following the split into different isms, it disintegrated into so-called re-segregation deconstructionisms called either feminist or otherwise (sometimes ethnic), demanding historical revision and justice to be done by a re-division of the chance-giving cards. For instance, in the sanctum of Yale feminist jurisprudence presented itself in interjections, the sentimentalism of injuries, which the champions of intellectual methodicalness, self-styled masters of reason, listened to with cold faces. When they asked for its theory of knowledge and methodology, the answer was a more impetuous cry of pain, since-I realised-all this was just showing the scandal of domination until now (with cathatonic anger flung always in face of the "male chauvinism of white domination"), namely, that today's female revolutionists did not even have vocabulary with which they could express themselves. "From what might we gather"--they said, mostly with contemptuous rejection-"even if the Bible also speaks by you and for you?". Well, after such representatives had experimented, with a foundation based on narrative jurisprudence, how to ontologise law through the style analysis of the language of legal processes, that is, how to reveal from behind its striking neutrality the relations of domination as a basic structure (which they felt intolerable), such legal theories began slowly wandering to the domain of literature (of course, not to the European or American versions, which they hated, but to their black, latino or hispanic variations)-in the United States of America, at the end of the millennium, following the barbarian coming into power of the generation of students who rioted in 1968-since there was neither law nor theoretical demand in their production but sheer emotional selfconditioning and claims (that could otherwise be received with full respect). ${ }^{13}$ Under such

13 As formulated by T. Nagy: Narratív tematika a kortárs amerikai jogelméletben [Narrative topics in contemporary American legal theorising]. Szeged, 2003, 22: "Writings by representatives of feminist jurisprudence and race-consciousness [...] begin look like literary texts proper.". Or, it may be claimed that "Kafka's The Trial is as good a jurisprudence as any other legal theory". Gräzin, I.: On Myth, Considered as a Method for Legal Thought. Law and Critique, 15 (2004), 159-181, abstract. 
conditions, not even the literary moment was too empathetic with them in the sense of European refinement, as the whole white male kit-from Homeros to Eugen Ionescu-could have been thrown away with pleasure in exchange for a good Puerto Rican woman slave story or for any pretext of female humiliation.

Law and Peace. Law and Modernisation. And Development, and Language, and Economy, and Literature--and all along the prayer-mill, in order to speak, having somewhat transcended Marxism, à propos of law in terms of political action and of the claim of a new class heralding new conquests, instead of law in a genuine sense or the morality and human values underlying it. Or, literature is just a pretence here ${ }^{14}$-with anonymous stories, instead of the civilisational meditations and debates of thousand years, as portrayed by Sophocles, Jean Racine, William Shakespeare, Johann Wolfgang Goethe, or just Albert Camus and Friedrich Dürrenmatt-because those rebels' demands, as sensed momentarily, can now be declared.

The French version of Law and Literature ${ }^{15}$ is, as referred to earlier, dynamically forming but its footing is lost and the road missed, as for the time being it is hardly more than some panting feeding generated by the feeling of being overdue. ${ }^{16}$ Of course, I believe that it may finish by borrowing the American naming patterns without following the latter's fashionable zigzags, and will strengthen as an auxiliary branch of studying law, and standing for interdisciplinarity itself, ${ }^{17}$ as mixed with specific literary and artistic analysis.

14 When it serves mere rhetorical purposes by signalling the legal absurdity of police actions exemplified by, e.g. Ghetti, M. R.: Seizure through the Looking Glass: Constitutional Analysis in Alice's Wonderland. Southern University Law Review, 22 (1994-1995), 231-254.

15 E.g. Henriot, E.: Moeurs juridiques et judiciaires de l'ancienne Rome d'après les poètes latins. I-III. Paris, 1865 [reprint: Aalen, 1973 and Pamploma, 2007].

16 Cf., e.g. Tzitzis, S.: Scolies sur les nomina d'Antigone représentés comme droit naturel. Archives de Philosophie du Droit, 33 (1988), 243-258; Biet, C.: La justice dans les Fables: La Fontaine et »le droit des gens«. Le Fablier [Revue des Amis de Jean de la Fontaine], (1992) 4, 17-24; Buschinger, D. (ed.): Le droit et sa perception dans la littérature et les mentalités médiévales. (Actes du Colloque du Centre d'Études Médiévales de l'Université de Picardie, Amiens, 17-19 mars 1989.) Göppingen, 1993; Malaurie, P.: Droit et littérature: Une anthologie. Paris, 1997; Littératures classiques [Toulouse] (2000), 40; Bouquet, P.-Voilley, P. (ed.): Droit et littérature dans le contexte suédois. Paris, 2000; Pech, T.: Conter le crime: Droit et littérature sous la Contre-Réforme: les histoires tragiques (1559-1644). Paris, 2000; Rubinlicht-Proux, A.: Le droit saisi par la littérature. [Thèse, 1997.] Villeneuve d'Ascq, 2001; Biet, C. (ed.): Droit et littérature, Europe 80 (2002) 876; Ost, F.-Van Eynde, L.-Gérard, P.--van de Kerchove, M. (eds): Lettres et lois: Le droit au miroir de la littérature. Bruxelles, 2001. As revealed by Ost, F.: Raconter la loi: Aux sources de l'imaginaire juridique. Paris, 2004. and Brogniez, L. (ed.): Droit et littérature: Dossier. Bruxelles, 2007, it is the late translation of Posner's provocative book [in note 12], unnoticed for a decade-Droit et littérature. Paris, 1996.--that would give a new impetus to an enervate culture reactivated now in France.

17 For instance, the course by M.-A. Frison and A.-G. Slama-<http://66.249.93.104/search?q =cache:odh5vYr71QQJ:www.sciences-po.fr/formation/cycle1/annee2/ouverture_2006/mafr_slama.pdf $+\% 22$ droit + et + litt $\% \mathrm{C} 3 \%$ A9rature $\% 22+$ frison-rocheandhl=huandgl=huandct $=$ clnkandcd $=1>-$ stops at the wisdom-concluded from the legende of Horus, Le Roman de Renart [around 1175, attributed to Pierre de Saint-Cloud], Shakespeare's The Merchant of Venice, Racine's Antigoné and Bérénice, Balzac's César Birotteau, Dostoyevskiy's The Brothers Karamazov, Anatole France's The Crime of Sylvester Bonnard, and finally, Kafka's The Trial-in accordance to which in contrast to EnglishAmerican literature, interested in procedural subtleties solely, the French literature focuses on cases when governmental measures can overweight law. 


\section{The German Study of Artistic Representations}

It is perhaps typical that the Germans-who, due to their past romanticism, founded on classical monographies (and in scholarly grounded manners), exemplify analyses that might result from the fullness of human beings' fallible swirl over the law-do not relegate to any wonder-expectation anything like Recht und Literatur or Recht und Kunst. Instead, they do their job. With scholarly thoroughness founded a century ago, they use the literary legacy to a spectacular depth. And through a series of historical overviews and panoramic processing ${ }^{18}$ of oeuvres rising like symbols - first of all by Shakespeare, Kleist and Kafka ${ }^{19}$-as well as monuments of world literature, ${ }^{20}$ they look for the literary precipitation of the law's drama

18 Cf., e.g. Keysser, A.: Recht und Juristen im Spiegel der Satire. I-II. Bad Rothenfelde, 1919; Rathe, K.: Der Richter auf dem Fabeltier. In: Weixlgärtner, A.-Planiscig, L. (ed.): Festschrift für Julius Schlosser zum 60. Geburtstage. Zürich, Leipzig and Wien, 1927, 187-205; Fehr, H.: Das Recht in der Dichtung [Kunst und Recht, II]. Bern, 1931. and Die Dichtung im Recht [Kunst und Recht, III]. Bern, 1936. and Die Tragik im Recht. Zürich, 1945; [Reichsminister] Frank, H.: Recht und Kunst. Leipzig, 1939; Nossack, H. E.: Das Verhältnis der Literatur zu Recht und Gerechtigkeit. Wiesbaden, 1968; Nentwig, M. A.: Richter in Karikatur und Anekdote. Köln, 1981; Würtenberger, T.: Satire und Karikatur in der Rechtsprechung. Neue Juristische Wochenschrift, (1983), 1144-1151; von Schirnding, A.: Recht und Richter im Spiegel der Literatur. Stuttgart, 1990; Kaufmann, A.: Recht und Gnade in der Literatur. Neue Juristische Wochenschrift, (1984), 1062-1069 and Recht und Gnade in der Literatur. Stuttgart, 1991; Molk, U. (ed.): Literatur und Recht: Literarische Rechtsfälle von der Antike bis in die Gegenwart. (Kolloquium der Akademie der Wissenschaften in Göttingen im Februar 1995.) Göttingen, 1996; Weber, H.: Annäherungen an das Thema »Recht und Literatur «. Baden-Baden, 2002; Weber, H. (ed.): Prozesse und Rechtsstreitigkeiten um Recht, Literatur und Kunst. BadenBaden, 2002; Weber, H. (ed.): Dichter als Juristen. Berlin, 2004; Weber, H.: Recht und Juristen im Bild der Literatur. Berlin, 2005; Kaul, S.: Fiktionen der Gerechtigkeit: Literatur, Film, Philosophie, Recht. Baden-Baden, 2005.

19 Cf., e.g. with respect to William Shakespeare, Kohler, J.: Shakespeare vor dem Forum der Jurisprudenz. Würzburg, 1883-1884 and Berlin, 1919, Illies, G.: Das Verhältnis von Davenants »The Law against Lovers" zu Shakespears »Measure for Measure» und »Much Ado about Nothing". Halle, 1900 and Schwarze, H.-W.: Justice, Law and Revenge: The Individual and Natural Order in Shakespeares Dramen. Bonn, 1971; in respect to Heinrich von Kleist see Caro, H. C.: Heinrich von Kleist und das Recht: Zum 100 jährige Todestage Kleist's. Berlin, 1911; Körner, J.: Recht und Pflicht: Eine Studie über Kleists »Michael Kohlhaas" und »Prinz Friedrich von Homburg«. Leipzig and Berlin, 1926; Fink, A.: Michael Kohlhaas-ein noch anhänginger Prozeß: Geschichte und Kritik der bisher ergangenen Urteile. In: Becker, H.-J. and al. (eds): Rechtsgeschichte als Kulturgeschichte. Festschrift für Adalber Erler zum 70. Geburtstag. Aalen, 1971, 37-108, Sendler, H.: Über Michael Kohlhaas-damals und heute. Berlin, 1985, Apel, F. (ed.): Kleists Kohlhaas: Ein deutscher Traum vom Recht auf Mordbrennerei. Berlin, 1987; Ensberg, P. (ed.): Recht und Gerechtigkeit bei Heinrich von Kleist. Stuttgart, 2002; and eventually, with respect to Franz Kafka see Hebell, C.: Rechtstheoretische und geistesgeschichtliche Voraussetzungen für das Werk Franz Kafkas, Analysiert an seinem Roman »Der Prozess«. Frankfurt am Main, 1993; Ferk, J.: Recht ist ein »Prozess«: Über Kafkas Rechtsphilosophie. Wien, 1999.

20 Cf., e.g. in chronological order of subjects, Funke, H.: Die sogennante tragische Schuld: Studie zur Rechtsidee in der griechischen Tragödie. Köln, 1963; Kaufmann-Bühler, D.: Begriff und Funktion der Dike in den Tragödien des Aischylos. [Diss.] Heidelberg, 1954; Gagarin, M.: Dike in the »Works and Days«. Classical Philosophy, 68 (1973), 81-94 and Dike in Archaic Greek Thought. Classical Philosophy, 69 (1974), 186-197; Kolb, H.: Himmlisches und irdisches Gericht in karolingischer Theologie und althochdeutscher Dichtung. Frühmittelalterliche Studien, 5 (1971), 284-303; Klibansky, E.: Gerichtsszene und Prozeßform in erzählenden deutschen Dichtungen des 
with the involved (and sometimes insoluble) dilemma that our fallible human history is to face. They reconstruct the law's world picture using other arts like fine $\operatorname{arts}^{21}$ and architecture, ${ }^{22}$ giving an opportunity to dissertations' monographic treatment. ${ }^{23}$ And all this

12.-14. Jahrhunderts. Berlin, 1925; Conrad, H.: Recht und Gerechtigkeit im Weltbild Dante Alighieris. In: Bauer, C. et al. (eds): Speculum Historiale: Geschichte im Spiegel von Geschichtsschreibung und Geschichtsdeutung. (Johannes Spötl aus Anlass seines 60. Geburtstages.) Freiburg, 1965. 59-66; Fehr, H.: Das Recht in der Sagen der Schweiz. Frauenfeld, 1955; Stuby, G.: Recht und Solidarität im Denken von Albert Camus. Frankfurt am Main, 1965.

${ }^{21}$ For a general overview see, e.g. Jessen, P. A.: Die Darstellung des Weltgerichts bis auf Michelangelo. Berlin, 1883; Voss, G.: Das Jüngste Gericht in der bildenden Kunst des frühen Mittelalters: Eine kunstgeschichtliche Untersuchung. Leipzig, 1884; von Moeller, E.: Die Augenbinden der Justitia. Zeitschrift für christliche Kunst, 18 (1905), 107-122 and 141-152, Die Waage der Gerechtigkeit. Zeitschrift für christliche Kunst, 20 (1907), 269 et seq. and 291 et seq. as well as 346 et seq., Die Zahlensymbolik in ihren Beziehungen zur Gerechtigkeit. Zeitschrift für christliche Kunst, 21 (1908), 137-148 and Das Auge der Gerechtigkeit. Das Recht, 21 (1908), 305-310; Fehr, H.: Das Recht im Bilde [Kunst und Recht, I]. Erlenbach-Zürich, München and Leipzig, 1923; Frommhold, G.: Die Idee der Gerechtigkeit in der bildenden Kunst: Eine ikonologische Studie. Greifswald, 1925; Holtze, F.: Die blinde Themis. Deutsche Juristen-Zeitung [Sonderausgabe (1925)]; Lederle, U.: Gerechtigkeitsdarstellungen in deutschen und niederländischen Rathäusern. [Diss.] Philippsburg, 1937; König, E.: Die sog. »Gerechtigkeitsbilder« der altniederländischen Malerei. In: Das Recht in der Kunst. Berlin, 1938, 198-208; Simon, K.: Abendlänische Gerechtigkeitsbilder. Frankfurt, 1948; Schoenen, P.: Die Kunst in Dienste des Rechts. In: Wolffram, J.-Kelin, A. (ed.): Recht und Rechtspflege in den Rheinlanden (1819-1969): Festschrift für 150 jährigen Bestehen der Oberlandsgerichts. Köln, 1969, 439-488 and 488-512; Kahsnitz, R.: Gerechtigkeitsbilder. In: Lexikon der christlichen Ikonographie. 2. (1970), 134-140; Dölger. F. J.: Die Sonne der Gerechtigkeit und der Schwarze: Eine religionsgeschichtliche Studie zum Taufgelöbnis. 2. Aufl. [repr. 1914.] Münster, 1971; Kissel, O.R.: Die Justitia: Reflexionen über ein Symbol und seine Darstellung in der bildenden Kunst. München, 1984; Bering, K.: Kunst und Staatsmetaphysik des Hochmittelalters in Italien: Zentren der Bau- und Bildpropaganda in der Zeit Friedrichs II. Essen, 1986; Latz, H.-Pleister, W.: Recht und Gerechtigkeit im Spiegel der europäischen Kunst. Köln, 1988; Sellert, W.: Recht und Gerechtigkeit in der Kunst. Göttingen, 1993; Bähli, M.: Das Recht am eigenen Bild. Basel, Genf and München, 2002.

22 E.g., all by Frölich, K.: Alte Dorfplätze und andere Stätten bäuerlicher Rechtspflege. Tübingen, 1938; Mittelalterliche Bauwerke als Rechtsdenkmäler. Tübingen, 1939; Stätten mittelalterlicher Rechtspflege im niederdeutschen Bereich. Gießen, 1946; Rechtsdenkmäler des deutschen Dorfs. Gießen, 1947 and Denkmäler mittelalterlicher Strafrechtspflege in Ost- und Mitteldeutschland. Giessen, 1946.

${ }^{23}$ As partial monographising see, e.g.--treating the oeuvre of Albrecht Dürer-Würtenberger, T.: Recht und Gerechtigkeit in der Kunst Albrecht Dürers. In: Kunst und Recht: Festgabe für Hans Fehr. I. Karlsruhe, 1948, 221-235; Schultheiss, W.: Albrecht Dürers Beziehungen zum Recht. In: Albrecht Dürers Umwelt: Festschrift zum 500. Geburtstag Albrecht Dürers am 21. Mai 1971. Nürnberg, 1971, 220 et seq; Eichler, H.: Recht und Reich bei Dürer. Innsbruck, 1976; in respect of further giants, Hegel, E.: Rembrandt und das Recht. In: Das Recht in der Kunst. Berlin, 1938, 170-181 and Jerz, M.-Daumier, H. (eds): Der Mensch und die Justiz. Boppard, 1966; as to other manifestations, Troescher, G.: Weltgerichtsbilder in Rathäusern und an Gerichtsstätten. In: Wallraf-Richartz-Jahrbuch, 11 (1939), 139 et seq; Kisch, G.: Gerechtigkeitsbilder auf Basler Renaissance-Medaillen. Zeitschrift für schweizerisches Recht, 72 (1953), 341-371 and Recht und Gerechtigkeit in der Medaillenkunst. Heidelberg, 1955; Gathen, A. D.: Rolande als Rechtssymbole: Der archäologische Bestand und seine rechtshistorische Stellung. Berlin, 1960; Engelhard, E.: Die Gerechtigkeit auf Ofenplatten. Landeskunde Vierteljahresblätter [Trier], 13 (1967), 7-10; von Hielmcrone, U.-D.: Die Darstellungen der Justitia im Landesteil Schleswig. [Diss.] Kiel, 1974; E. van Holk, L.: Justitia: Bild und Sinnbild 
is done so that both the genuine uncharted mystery of our human world, which composes the very substrate (background and medium, conditions and deep reasons) of legal problematisation in an almost limitless variegation, and our constant search for valuemediation, also weighing and balancing in cases of the apparently flat denial of values, can be shown by live examples.

Reaffirming the unerasable human moment that is hidden in the law, we may encounter further-and especially Spanish ${ }^{24}$-contributions as well, occasioned by literary ${ }^{25}$ and fine $\operatorname{arts}^{26}$ pieces.

Interest is also rising in Hungary. ${ }^{27}$ It must be founded on monographisation, while its proper message can only be deciphered through essayism. For it may sound on "the »voice« of humaneness, which is recurrently muted by the impersonal procedures of law and the abstractions of decision-makers." 28

What it is all about is perhaps not simply bridging the gap between the law's proposition and the case of law-with unavoidable tensions confronting the general and the individual,

im 17. Jahrhundert in den Niederlanden. In: Carlen, L. (ed.): Forschungen zur Rechtsarchäologie und rechtlichen Volkskunde. Zürich, 1981, 155-199 and Eine mittelalterliche Rechtslegende und ihre Darstellung in der Kunst des 17. Jahrhunderts. In: Forschungen zur Rechtsarchäologie und rechtlichen Volkskunde, 5 (1983), 135-157; Becker-Moelands, M.-A.: Die Titelbilder juristischer Bücher. In: Forschungen zur Rechtsarchäologie und rechtlichen Volkskunde, 8 (1986), 41-77; Windisch, E.: Justitia: Porträt eines Mädchens, Porträt eines Vogels. In: Festschrift für Hildebert Kirchner zum 65. Geburtstag. München, 1985. 393-411.

${ }^{24}$ E.g. Obregón, J. R.: Examen crítico de algunas ideas de derecho público que se leen en Don Quijote. [Tesis.] Madrid, 1905; Martínez Val, J. M.: En torno al »Quijote«: Dos ensayos jurídicos. Cuidad Real, 1960; Batiza, R.: Don Quijote y el Derecho. México, 1964; Pérez Fernández, J.: Ensayo humano y jurídico de »El Quijote«. Madrid, 1965; Castañeda, J. E.: El Derecho et el Quijote. Revista de Derecho y Ciencias Politicas [Lima], 37 (1973), 5-67 and 199-250; Ciuro Caldani, M. Á.: Filosofia, Literatura y Derecho: Estudios y notas. Rosario, 1986; Fina Sanglas, A.: Justicia y literatura. Barcelona, 1993; Echevarría, R. G.: Love and the Law in Cervantes. New Haven and London, 2005; Talavera, P.: Derecho y literatura: El Reflejo de lo jurídico. Granada, 2006; Barchet, R. A. (ed.): El Derecho en la épocy del Quijote. (Seminario Internacional, organizado por el Instituto de Estudios Jurídicos Internacionales Conde de Aranda: Universidad Rey Juan Carlos, Campus de Vicálvaro, del 15 al 17 de marzo de 2005.) Pamplona, 2006; Prat Westerlindh, C.: La justicia en »El Quijote«. Madrid, 2006; González, J. C. (ed.): Implicación derecho literatura: Contribuciones a una teoría del Derecho. Granada, 2008.

25 E.g. Carpi, D. (ed.): Shakespeare and the Law. Ravenna, 2003 and Meyer, M. J. (ed.): Literature and Law. Amsterdam, 2004.

${ }^{26}$ E.g. Zdekauer, L.: L'idea della Giustizia e la sua immagine nelle arti figurative. Macerata, 1909 and Iustitia: Immagine e idea. Siena, 1913; Stechow, W.: Römische Gerichtsdarstellungen von Rembrandt und Bol. Oud-Holland, 46 (1929), 134-139; Deonna, W.: La Justice à l'Hotel de Ville de Genève et la fresque des juges aux mains coupés. Zeitschrift für schweizerische Archäologie und Kunstgeschichte, 11 (1950), 144-149; Jónsdóttir, S.: An 11th Century Byzantine Last Judgement in Iceland. Reykjavík, 1950; Overdiep, Door Mr. G.: Justitia, waar is uw blinddoek? In: Pro excolendo iure patrio, 1761-1961. Groningen, 1961, 87-122; van Lohuizen-Mulder, M.: Raphael's Images of Justice, Humanity and Friendship: A Mirror of Princes for Scipione Borghese. Wassenaar, 1977.

27 As an auxiliary to legal history, it can also found an interdisciplinary field of research as exemplified by, e.g. Kajtár, I.: Bevezetés a jogi kultúrtörténetbe (Introduction to the cultural history of law). Budapest and Pécs, 2002.

28 Nagy: Narratív tematika... op. cit. 6. 
the abstract and the concrete (as interwar legal philosophies claimed steadily ${ }^{29}$ )-and perhaps it is not even about some refining correction or supplementation (which motivated the French movement ${ }^{30}$ ). Instead, it is more about live meditation, professional methodicalness stepped back in order to gain further perspectives ${ }^{31}$ and renewed reflection from a distance, so that the underlying reason for our profession can be recurrently rethought.

\section{Some Literary Reconsiderations}

Due to the artistic expression and internal inexhaustibility of literary presentation, in the parallel examination of law and literature even apparent truisms can feature as genuine enigmas, fertilising theoretical research.

As to the necessary connection between the transcendence of final issues and the worldly undertaking of law, one may draw from The Tragedy of Man by Imre Madách ${ }^{32}$ (dramatist, surpassing his teacher ${ }^{33}$ even as a professional thinker) the wisdom that may unite faith, hope and love. For "in the act of man steadily committing mistakes, who often fights in vain and without success, the verification of the existence of God is not included. To the contrary, it is man having languished in unsuccessful struggle and discouraged by the uncertain end, who needs strong trust in God in order to be able to restore the negative balance of his struggles having a penchant for denying life itself, towards life and further struggle." Such optimism is only feasible if it is oriented toward personal felicity through one of his or her community, which is precisely embodied by the Hungarian traditional public law focus on community, as testified to by the doctrine of the Holy Crown, in contrast to the Germanic model of private law dedication, rooted in their feudal experience. ${ }^{34}$

For me, the Kleistean story of Michael Kohlhaas used to provide a basic cultural anthropological exemplification of the ancient wisdom, which, enshrined by the Jewish, Islamic and autochthonous cultures, subordinates conflict-resolution to community peace (the classic 'shalom'), to prevent, from the beginning, the unravelling of any one-sidedness without scale and proportion, especially of the relentless fights for justice. ${ }^{35}$ Albeit for others

${ }_{29}$ As collected from the representative authors, see Somló, F.: Schriften zur Rechtsphilosophie. (ed. Varga, Cs.) Budapest, 1999; Moór, J.: Schriften zur Rechtsphilosophie. (ed. Varga, Cs.) Budapest, 2006; Varga, Cs. (ed.): Die Schule von Szeged: Rechtsphilosophische Aufsätze von István Bibó, József Szabó und Tibor Vas. Budapest, 2006 and Losonczy, I.: Abriß eines realistischen rechtsphilosophischen Systems. (ed. Varga, Cs.) Budapest, 2002.

30 Ost, F.-Van Eynde, L. in <http://66.249.93.104/search?q=cache:AJD4ire0GaMJ:www.dhdi. free.fr/recherches/theoriedroit/articles/osteyndelit.doc $+\% 22 \mathrm{droit}+$ et + litt $\% \mathrm{C} 3 \% \mathrm{~A} 9$ rature $\% 22+\mathrm{Ost} \& \mathrm{hl}$ $=$ hu\&gl=hu\&ct=clnk\&cd=12> speaks about, e.g. scholarly diversion ("as a humanist decoration apt to clarify the dryness of legal evidence"), critical subversion ("revealing the king naked and the song's false disharmony"), and foundational conversion ("when the narrative turns to be the basis for making it »thought over«, »evaluated «, moreover, »prescribed « as well").

31 "perspective on" in Posner, R. A.: Remarks on Law and Literature. Loyola University Chicago Law Journal, 23 (1991-1992), 181-195, quote at 182.

32 Moór, Gy.: Az Ember Tragédiája jogbölcseleti megvilágitásban [The »Tragedy of Man« in the light of legal philosophy]. Budapest, 1923. Cf. also <http://en.wikipedia.org/wiki/Imre_Madách> and The Tragedy of Man trans. Szirtes, G. in <http://mek.niif.hu/00900/00918/html/index.htm>.

${ }^{33}$ In so far as running counter to his master, Anton Virozsil, he will be an early follower of the doctrine of "natural law with variable content", theorised by Rudolf Stammler. Ibid. 13-14.

34 Quote at ibid. 5, and comment at 15.

35 Cf. Varga, Cs.: Lectures on the Paradigms of Legal Thinking. Budapest, 1999, para. 2.3.3. 
(and also in a self-justifying manner) this is just the allegory of paradoxes, since "the verdict will repeat then the offence convicted by itself", as "Kohlhaas would have never achieved his justice [...], if he had not taken it himself", as a result of which, however, "the total compensation [...] will deprive him of his life". ${ }^{36}$

Or, through the dramatic presentation of one of the earliest known allegories of rival interests and roles, as played by Sophocles' Antigone, we may tentatively consider laying aside all our resultant sympathy for a moment, since we may be convinced that it is the espousal of Antigone's rejection of any compromise that will force Kreon to act. For the community's very survival would be endangered by an equal acknowledgment of the mixed qualities of an emotionally fighting party, led by tradition, on the one hand, and of the conspirator, on the other, in the brother departed. That is to say exactly that the simpleminded inflexibility of Antigone may exclude for Kreon the possibility of any wise, humanely refined offer, with a compromise achieving a counter position without a final sharpening, while looking for any choice for cooperation. ${ }^{37}$

Or, pushing up to the final sense Dostoyevsky's permanently rooted humane thoughts, we may dawn on the idea that offences are neither to be matched with one another, nor are they to be matched with their penalties, since-as we may learn from common wisdom as opposed to the forcedly impersonal typification of the law-"[e]very story is individual, while the final sentence is however the same". ${ }^{38}$

\section{Conclusion}

In the end, we may realise that for such an interest, it is not literature that is from the outset endowed with some predestined role. As the embodiment of a type of thinking, literature is the symbol and synonym of reflected life, a field where "the mystery manifesting itself through different fates" 39 can be represented. Otherwise expressed, literature is hardly anything other here than a substitute for theology, rooted in earthly existence as a supply to foster feeling transcendence. Law, too, came into being to serve this, although we cannot explain what it is originally and what law could serve it the best, and how. Nevertheless, the closest to the issue may be the Confessiones by Augustinus (preceding the time when theology as a distinct scholarship was born), since it targeted our faith in God as humanity's basic need, expressed by love streaming from humanity.

36 Miller, J. H.: Laying down the Law in Literature: The Example of Kleist. Cardozo Law Review, 11 (1989-1990), 1491-1514, quote at 1500, note 29 and at 1501.

37 Posner: Remarks on Law and Literature. op. cit. 183 and 193-194.

38 Murav, H.: Dostoïevski et le droit. Europe 80 (2002), 115. Cf. Varga: Lectures on the Paradigms... op. cit. para. 2.3.1.5.

39 Ost et al.: Lettres et lois... op. cit. 